\title{
Nano rare-earth oxides induced size-dependent vacuolization: an independent pathway from autophagy
}

This article was published in the following Dove Press journal:

International Journal of Nanomedicine

16 August 2010

Number of times this article has been viewed

\section{Ying Zhang \\ Chenguang Yu \\ Guanyi Huang \\ Changli Wang \\ Longping Wen}

Hefei National Laboratory for Physical Sciences at Microscale, and School of Life Sciences, University of Science and Technology of China, Hefei, China
Correspondence: Longping Wen

Hefei National Laboratory for Physical

Sciences at Microscale, and School

of Life Sciences, University of Science

and Technology of China,

Hefei 230027, China

Tel +8655I 3600426

Email lpwen@ustc.edu.cn
Abstract: Four rare earth oxides have been shown to induce autophagy. Interestingly, we often noticed plentiful vacuolization, which was not always involved in this autophagic process. In this study, we investigated three other rare-earth elements, including Yttrium (Y), Ytterbium (Yb), and Lanthanum (La). Autophagic effect could be induced by all of them but only $\mathrm{Y}_{2} \mathrm{O}_{3}$ and $\mathrm{Yb}_{2} \mathrm{O}_{3}$ could cause massive vacuolization. $\mathrm{Y}_{2} \mathrm{O}_{3}$ and $\mathrm{Yb}_{2} \mathrm{O}_{3}$ treated by sonication or centrifugation to reduce particle size were used to test vacuolization level in HeLa cell lines. The results showed that rare earth oxides-induced vacuolization is size-dependent and differs from autophagic pathway. To further clarify the characteristics of this autophagic process, we used MEF Atg-5 (autophagy associated gene 5) knockout cell line, and the result showed that the autophagic process induced by rare earth oxides is Atg-5-dependent and the observed vacuolization was independent from autophagy. Similar results could also be observed in our tests on 3-methyladenine(3-MA), a well-known autophagy inhibitor. In conclusion, for the first time, we clarified the relationship between massive vacuolization and autophagic process induced by rare earth oxides and pointed out the size effect of rare earth oxides on the formation of vacuoles, which give clues to further investigation on the mechanisms underlying their biological effects.

Keywords: size-dependent, rare-earth oxides, vacuolization, autophagy

\section{Introduction}

Rare earth elements, a category of compounds including 17 different members with similar chemical properties, consist of scandium, yttrium, and the 15 lanthanides. Their increasing application has been intensively reported over the past few years in fields of superconductor, electronic polishers, and refining catalysts. Recently, rare earth oxides were reported to induce various biological functions in vitro, including antiviral activity. ${ }^{1,2}$ Protein adsorption and cellular uptake, ${ }^{3}$ oxidative stress, ${ }^{4-7}$ cell differentiation ${ }^{8}$ and neuroprotection. ${ }^{9,10}$ Under this circumstance, the study for mechanism about the biological effects of nano rare earth oxides will be important to their future biomedical applications.

Autophagy, a highly-regulated cellular process for eliminating long-lived proteins and damaged organelle components via lysosomal mechanism, has received much attention.

Interestingly, nanoparticles have been identified as a novel class of autophagy inducers as progress in the field of nanotechnology allows for a deeper understanding of their effects on live organisms. Our previous report has shown that autophagy-inducing activity is a common biological effect for rare-earth elements, including samarium 
$(\mathrm{Sm}) /$ europium $(\mathrm{Eu})$, and gadolinium $(\mathrm{Gd}) /$ terbium $(\mathrm{Tb}) .{ }^{11}$ The evidence sheds light on further investigation upon the specific characteristics of vacuolization and autophagic effect induced by oxide particles.

The most interesting characteristic of nanoparticles is the quantum size effect due to their minute size. Therefore, size effect might play an important role in nanomaterialinduced biological functions. Here we presented an interesting phenomenon that certain rare earth oxides, referred as $\mathrm{Y}_{2} \mathrm{O}_{3}$ and $\mathrm{Yb}_{2} \mathrm{O}_{3}$, could cause size-dependent vacuolization accompanied with autophagic effect. Such vacuolization is also proved to be independent from the autophagic process and occurred coincidentally. The present study showed the physical characteristics like size of rare earth oxides could hold important influences on their biological effects such as vacuolization and clarified the relationship between autophagy and vacuolization. These results will help to understand the role nanoparticles act in the autophagic pathway and develop applications of nano rare earth oxides in medical therapy.

\section{Materials and methods}

\section{Reagents}

Microtubules associated protein light chain 3 (LC3) plasmid, immortalized wild-type MEF and Atg5 $5^{-/-} \mathrm{MEF}$ cells were donated by N Mizushima (The Tokyo Metropolitan Institute of Medical Science, Tokyo, Japan). GFP-LC3/HeLa cells were selected and established in the laboratory. Rare earth oxides (99.9\% pure) were from Huizhou Ruier Company (Huizhou, China). Nano $\mathrm{Y}_{2} \mathrm{O}_{3}$ powder $(99.995 \%,<50 \mathrm{~nm}$ particle size) was purchased from Aldrich Chemical (Milwaukee, WI, USA). Rapamycin, trehalose, monodansylcadaverine (MDC), 3-methyladenine (3-MA), were all purchased from Sigma (St Louis, MO, USA). MitoTracker Red (MT) and LysoTracker Red (LT) were from Invitrogen (Carlsbad, CA, USA). LC3 antibody and GAPDH antibody were purchased from Novus (Littleton, CO, USA) and Santa Cruz Biotechnology (Santa Cruz, CA, USA), respectively. All cell culture reagents were purchased from Gibco (Carlsbad, CA, USA). Reagents were dissolved in phosphate-buffered saline (PBS), distilled water, ultrapure water ( $\mathrm{pH}$ 6.7; Milli-Q, Bedford, MA, USA) or dimethyl sulfoxide according to manufacturer's instructions.

\section{Cell culture}

All cells were grown continuously as a monolayer at $37^{\circ} \mathrm{C}$ and $5 \% \mathrm{CO}_{2}$ in Dulbecco's modified Eagle's medium supplemented with $10 \%$ fetal bovine serum, $100 \mu \mathrm{g} / \mathrm{mL}$ penicillin, and $100 \mu \mathrm{g} / \mathrm{mL}$ streptomycin.

\section{GFP-LC3 green dot aggregation assay}

GFP-LC3/HeLa cells were observed under fluorescent microscopy (Olympus IX71, Tokyo, Japan), cells with at least five visible GFP-LC3 dots were identified as GFP-LC3 dot formation.

\section{Autophagic marker dye staining}

GFP-LC3/HeLa cells were grown in 96-well plates and treated with rare earth oxides solution $(50 \mathrm{~g} / \mathrm{mL}$ for $24 \mathrm{~h}$, then were treated for $15 \mathrm{~min}$ with $10 \mu \mathrm{M}$ MDC, $20 \mathrm{nM}$. MT and $75 \mathrm{nM}$ LT, respectively. After washing twice with PBS, cells were examined under fluorescent microscopy.

\section{Immuno-blotting}

Cells were cultured in 24-well plates. After being trypsinized and collected, cells were resuspended with the lysis buffer $(0.5 \%$ Nonidet P-40/10 mM Tris-HCl, $\mathrm{pH}$ $7.5 / 100 \mathrm{mM} \mathrm{NaCl}$ ) with an equal volume of $2 x$ SDS sample buffer, boiled for $10 \mathrm{~min}$. Proteins were separated on a $12 \%$ SDS/PAGE gel and transferred to nitrocellulose membrane (Amersham, Freiburg, Germany). After blocking with 5\% nonfat dry milk, the nitrocellulose membrane was incubated for $3 \mathrm{~h}$ with a primary antibody at an appropriate dilution, extensively washed, incubated with horseradish peroxidase-conjugated secondary antibody $(1: 10,000$ dilution) for $1 \mathrm{~h}$, and finally visualized with enhanced chemiluminescence (ECL) kit (Biological Industries, Beit Haemek, Israel).

\section{Transmission electron microscope}

Nano rare earth oxides were characterized by a JEOL-2010 high-resolution transmission electron microscopy (HRTEM; JEOL, Tokyo, Japan) at $200 \mathrm{kV}$. To visualized autophagic vesicles (AVs), GFP-LC3/HeLa cells were grown in the 6-well plates and exposed under rare earth oxides for $24 \mathrm{~h}$. After collection, cells were fixed in $0.1 \mathrm{M}$ Na-phosphate buffer ( $\mathrm{pH} 7.4$ ) containing 2\% glutaraldehyde for $1 \mathrm{~h}$. After postfixing in 1\% OsO4 at room temperature for $60 \mathrm{~min}$, cells were dehydrated with a graded series of ethano, and embedded in epoxy resin. Areas containing cells were block mounted and cut into ultrathin sections. The sections were stained with uranyl acetate and lead citrate and examined with a transmission electron microscope (JEOL-1230; JEOL).

\section{Statistical analysis}

All data were expressed as mean \pm SEM. and analyzed by two-tailed Student's $t$-tests. 


\section{Results}

\section{Vacuolization is observed in GFP-LC3/ HeLa cells treated with $\mathrm{Y}_{2} \mathrm{O}_{3}$ and $\mathrm{Yb}_{2} \mathrm{O}_{3}$, but not $\mathrm{La}_{2} \mathrm{O}_{3}$ particles}

In HeLa cells stably expressing GFP-LC3 plasmid, we added $\mathrm{Y}_{2} \mathrm{O}_{3}, \mathrm{Yb}_{2} \mathrm{O}_{3}, \mathrm{La}_{2} \mathrm{O}_{3}(50 \mu \mathrm{g} / \mathrm{mL})$ into cell culture medium and observed the cell morphology as well as LC3 dot aggregation under fluorescent microscopy. Massive vacuoles became visible $24 \mathrm{~h}$ after the $\mathrm{Y}_{2} \mathrm{O}_{3}, \mathrm{Yb}_{2} \mathrm{O}_{3}$ treatment. Also we could locate the LC3 aggregation in the cell and most vacuoles were partially enclosed by LC3 dot. On the other hand, in HeLa cells treated with $\mathrm{La}_{2} \mathrm{O}_{3}$, only LC3 dot aggregation could be seen (Figure 1a). And the $\mathrm{Yb}_{2} \mathrm{O}_{3}$ particles-induced vacuoles were also presented under the light microscopy (Figure 1b). The dose effect and time curve of GFP-LC3 dot formation showed that the treated punctuate GFP cells accumulated as dose and time increased. And cells treated with $50 \mu \mathrm{g} / \mathrm{mL}$ $\mathrm{Yb}_{2} \mathrm{O}_{3}$ for $24 \mathrm{~h}$ were enough to induce $80 \%$ cells punctuation (Figure 1c, d). Similar assays on vacuolization suggested 75\% cells presented at least one visible vacuole after treatment with $100 \mu \mathrm{g} / \mathrm{mL} \mathrm{Yb}_{2} \mathrm{O}_{3}$ for $24 \mathrm{~h}$ (Figure 1e,f).

\section{GFP-LC3 dot aggregation induced by nano rare earth oxides represents a classical Atg-5 dependent autophagy process}

To prove that $\mathrm{Yb}_{2} \mathrm{O}_{3}$-induced LC3 dot aggregation is specific and autophagy is involved, we presented several pieces of evidence. Under the transmission electron microscopy (TEM), the majority of $\mathrm{Yb}_{2} \mathrm{O}_{3}$-treated HeLa cells, but not controlled cells, indicated features of autophagic vacuoles (AVs), mostly in late phases (Figure 2a). Consistently, most of the GFP-LC3 dots viewed under fluorescent microscopy could also be stained by MDC, which specifically stains acidic vesicles including autolysosomes (Figure 2b). Similarly, co-localization could be identified between GFP-LC3 green dots and LT staining pattern (Figure 2c). Moreover, autophagic vacuoles in most cases contain parts of mitochondria organelles and thereby could be stained by MT dye, as confirmed in Figure 2d. The most persuasive evidence of autophagy occurrence was known to be type conversion of LC3 protein. As shown from Figure 2e, after $\mathrm{Yb}_{2} \mathrm{O}_{3}$-treatment, LC3 protein underwent type conversion from LC3 Type I (18 kd) to endogenous Type II (16 kd). And the total mount of LC3 Type II gradually accumulated in $48 \mathrm{~h}$, indicating a proceeding autophagy process. All the above experiments exhibited similar results in $\mathrm{Y}_{2} \mathrm{O}_{3}$ treatment group (data not shown). As both an increase in autophagosome production and an impaired autophagic degradation can make autophagic vacuoles accumulate in the cells, we examined the degradation level of P62, which is a selective substrate of autophagy. Our results showed that in HeLa cells treated with $\mathrm{Y}_{2} \mathrm{O}_{3}, \mathrm{Yb}_{2} \mathrm{O}_{3}, \mathrm{La}_{2} \mathrm{O}_{3}$ for $24 \mathrm{~h}$, the degradation rate of $\mathrm{P} 62$ increased significantly compared with control group. This supporting evidence strongly indicated that a true and complete autophagy process occurred during the vacuolization induced by $\mathrm{Yb}_{2} \mathrm{O}_{3}$ and $\mathrm{Y}_{2} \mathrm{O}_{3}$ particles.

\section{Vacuolization induced by $\mathrm{Y}_{2} \mathrm{O}_{3}$ particles are size-dependent}

Under microscopy, the oxides particles were observed to circle around vacuoles (data not shown), making us to assume that vacuole formation was not related to autophagy, but the particles themselves. Considering that green GFP-LC3 dot in $\mathrm{La}_{2} \mathrm{O}_{3}$-treated cells scattered intracellularly, we tend to believe that the vacuolization coupled with autophagy was size-dependent, which means only particles (or particle aggregates that often existed in water solution) larger than a certain size were able to induce vacuolization. To verify this, we added $\mathrm{Y}_{2} \mathrm{O}_{3}$ nanopowder $(50 \mu \mathrm{g} / \mathrm{mL})$ into cell medium, and noticed no apparent vacuolization after $24 \mathrm{~h}$, whereas GFP-LC3 dot aggregation still existed (Figure 3a). Data from dynamic light scattering (DLS) showed the average size of imputed $\mathrm{Y}_{2} \mathrm{O}_{3}$ nanoparticles aggregates was $177 \mathrm{~nm}$, while the average size of domestic-made $\mathrm{Y}_{2} \mathrm{O}_{3}$ used in Figure 1 was $856 \mathrm{~nm}$ (Figure 3b), which is consistent with our TEM images (Figure 3c). Furthermore, we extracted supernantant of $\mathrm{Y}_{2} \mathrm{O}_{3}$ used in Figure 1 after centrifugation at $1600 \mathrm{rpm}$. DLS data showed the average size of $\mathrm{Y}_{2} \mathrm{O}_{3}$ supernantant was $299 \mathrm{~nm}$ (Figure 3e), as well as TEM images (Figure 3f). As supposed, the supernantant containing smaller particle aggregations caused less vacuoles in HeLa cell lines (Figure 3d).

\section{Vacuolization induced by $\mathrm{Yb}_{2} \mathrm{O}_{3}$ particles are size-dependent}

Sonication is a classical physical method to decrease average size of nanoparticle aggregates in solvent. Compared to $\mathrm{Yb}_{2} \mathrm{O}_{3}$ particles used in Figure 1, after sonication $\mathrm{Yb}_{2} \mathrm{O}_{3}$ could cause similar LC3 aggregation effects yet a significant reduction of vacuolization, both in size and number (Figure 4a). As we could see from DLS data and TEM images, the average size of $\mathrm{Yb}_{2} \mathrm{O}_{3}$ fell from $993 \mathrm{~nm}$ to $279 \mathrm{~nm}$ after sonication (Figure 4b,c). We also performed staining assay as well as LC-3 type conversion to prove autophagy was not affected 
A


B
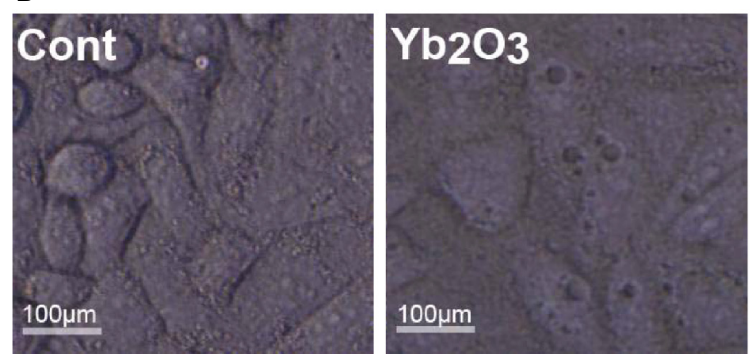

C

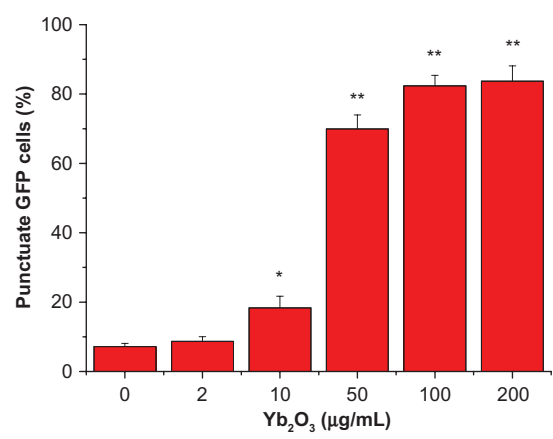

E

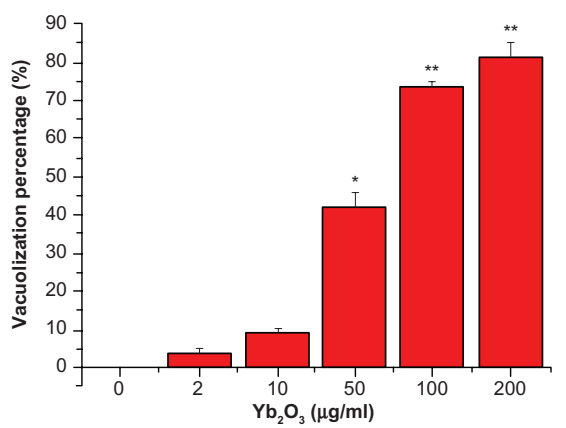

D



F



Figure I Massive vacuolization of GFP-LC3/HeLa cells induced by $\mathrm{Y}_{2} \mathrm{O}_{3}, \mathrm{Yb}_{2} \mathrm{O}_{3}$ but not $\mathrm{La}_{2} \mathrm{O}_{3}$. A) Direct observation of vacuolization and GFP-LC3 dot aggregation via fluorescent microscopy (treated with $50 \mu \mathrm{g} / \mathrm{mL}$ oxide particles, $24 \mathrm{~h}$ ). B) The vacuoles in GFP-LC3/HeLa cells treated with Yb $\mathrm{O}_{3}(50 \mu \mathrm{g} / \mathrm{mL}, 24 \mathrm{~h}$ ). C) GFP-LC3 aggregation dose effect after treatment with $\mathrm{Yb}_{2} \mathrm{O}_{3}$ for $24 \mathrm{~h}$. D) GFP-LC3 aggregation time curve after treatment with $50 \mu g / \mathrm{mL} \mathrm{Yb}_{2} \mathrm{O}_{3}$. E) Vacuolization percentage dose effect in GFP-LC3/HeLa cells after treatment with $\mathrm{Yb}_{2} \mathrm{O}_{3}$ for 24 h. F) Vacuolization percentage time curve essay after treatment with $100 \mu \mathrm{g} / \mathrm{mL} \mathrm{Yb} \mathrm{O}_{3}$. Mean $\pm \mathrm{SEM} ; \mathrm{n}=3$.

Notes: $* P<0.05 ; * * P<0.01$. 


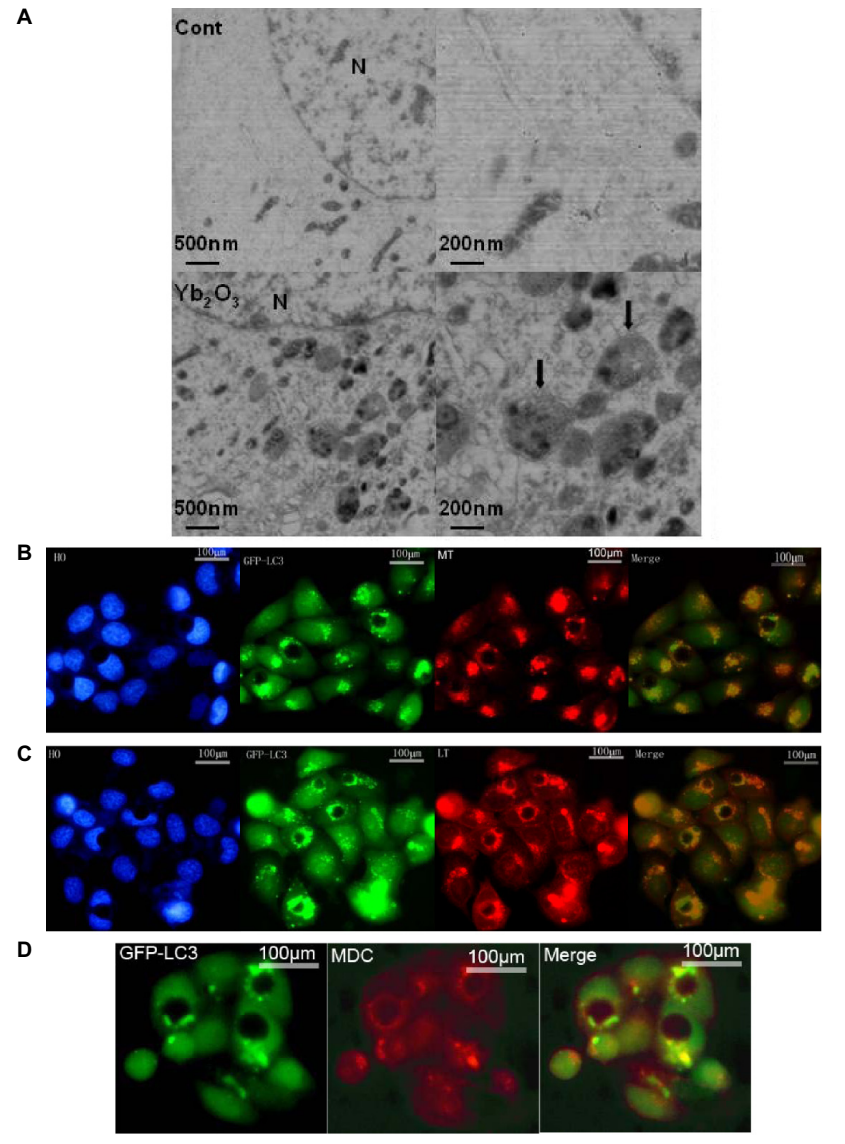

E


$\mathbf{F}$

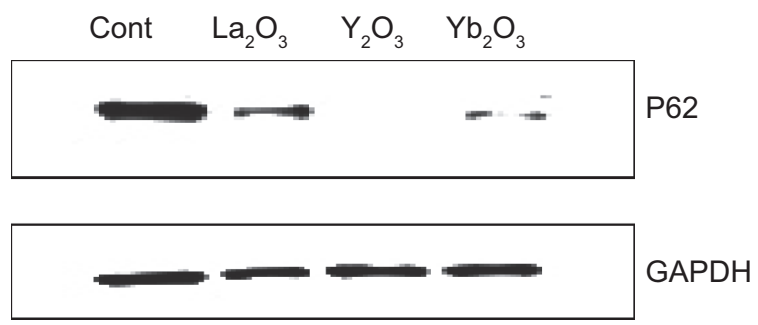

Figure 2 The vacuolization of GFP-LC3/HeLa cells, induced by $\mathrm{Y}_{2} \mathrm{O}_{3}, \mathrm{Yb}_{2} \mathrm{O}_{3}$, is coupled with a typical autophagic process. A) Ultrastructural features of autophagosomes treated with PBS or $50 \mu \mathrm{g} / \mathrm{mL}$ of $\mathrm{Yb}_{2} \mathrm{O}_{3}$ for 2 days, as revealed by TEM. Right panels are high magnification images of left panels. Typical AVs (black arrows) are indicated, b-d. Autophagic marker dye staining assay on GFP-LC3/HeLa cells treated with $50 \mu \mathrm{g} / \mathrm{mL}$ Yb2O3 for $24 \mathrm{~h}$. B) IOMM MDC, I5 min. C) $75 \mathrm{nM}$ LysoTracker Red (LT), 15 min. D) 20 nM MitoTracker Red (MT), 15 min. Hoechst $33342(\mathrm{HO})$ dye was used to show nucleus subcellular location. E) LC3 protein type conversion and the accumulation of LC3-II in $48 \mathrm{~h}$, Cells were treated with $50 \mu \mathrm{g} / \mathrm{mL}$ $\mathrm{Yb}_{2} \mathrm{O}_{3}$ and then subject to the western blotting. GAPDH was loading control. F) P62 protein degradation rate in autophagy pathway was measured by western blotting. Cells were treated with $50 \mu \mathrm{g} / \mathrm{mL} \mathrm{Yb}_{2} \mathrm{O}_{3}$ for $24 \mathrm{~h}$ and then analyzed. GAPDH was loading control. in this size-reducing process. GFP-LC-3 dots could be co-localized by MDC, LT, and MT dye and the type conversion from LC-3 type I to endogenous type II was observed in both sonicated $\mathrm{Yb}_{2} \mathrm{O}_{3}$ and $\mathrm{Y}_{2} \mathrm{O}_{3}$ nanoparticles-treated HeLa cell lines (Figure 4d,e).

\section{Vacuolization and autophagy are triggered independently}

Results in Figures 3 and 4 strongly imply that vacuolization and autophagy may be two independent, rather than interrelated, events. Here we use Atg $5^{-/-}$MEF cells to block out the Atg-5-dependent autophagic cycle, and in western blotting analysis, neither classical autophagy inducers (trehalose, rapamycin) nor rare earth oxides were able to enter autophagy pathway in Atg5 $5^{-/-}$MEF cells, whereas they both acted normally in immortalized wildtype MEF cells, indicating a well established system (Figure 5a). Consistent with our previous assumption, apparent vacuolization was still observed in $\mathrm{K}-\mathrm{MEF}$ cells treated with $50 \mu \mathrm{g} / \mathrm{mL} \mathrm{Y}_{2} \mathrm{O}_{3}, \mathrm{Yb}_{2} \mathrm{O}_{3}$ for $24 \mathrm{~h}$ under light microscopy (Figure 5b). Meanwhile, 3-MA, a known inhibitor of autophagy pathway through regulating the phosphor-inositol 3-kinase (PI3K) pathway, caused a reducing GFP-LC3 dot aggregation, as well as the LC3 type II protein on western blotting. Predictably, the vacuolization induced by $\mathrm{Yb}_{2} \mathrm{O}_{3}$ in GFP-LC3/HeLa cells was not influenced by 3-MA, suggesting a different pathway from the autophagy process (Figure 5c).

\section{Discussion}

It has been known for a long time that the formation of numerous vacuoles under light microscopy is a response to some basic compounds, such as procaine, procainamide, and many others. ${ }^{12,13}$ Our results showed that some rare earth oxides could induce massive vacuolization in HeLa cell lines and they caused different vacuolization levels in a size-dependent mechanism. Actually, physical characteristics of nanomaterials such as size or shape are usually responsible for their special biological effects. A size-dependent autophagy-inducing effect of quantum dots in human mesenchymal stem cells was reported already. ${ }^{14}$ Also gold nanoparticles of various sizes were proved to be cytotoxic with different kinds of cell death. ${ }^{15}$ Such size effect might give a clue for the potential mechanism of the formation of vacuolization and relative responses in cells.

Previous reports demonstrated that wortmannin could induce the formation of giant vacuoles in several cell types and in a definite time window. ${ }^{16,17}$ Also, it is well known that wortmannin at concentrations that inhibited 
A
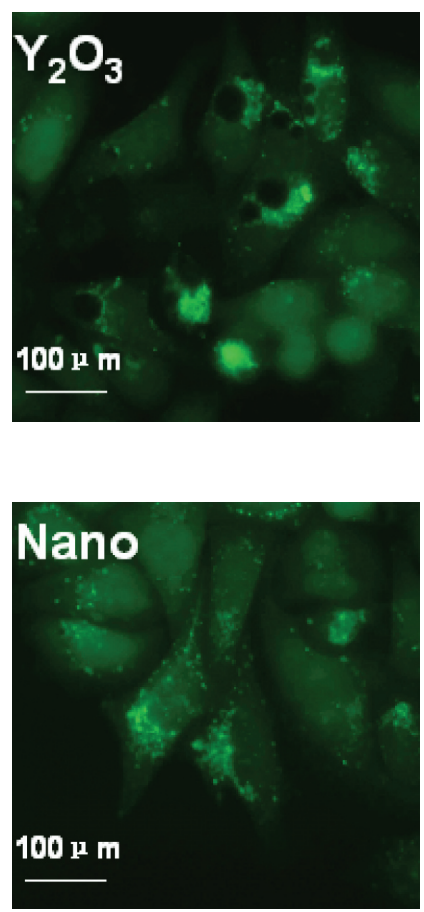

D



B
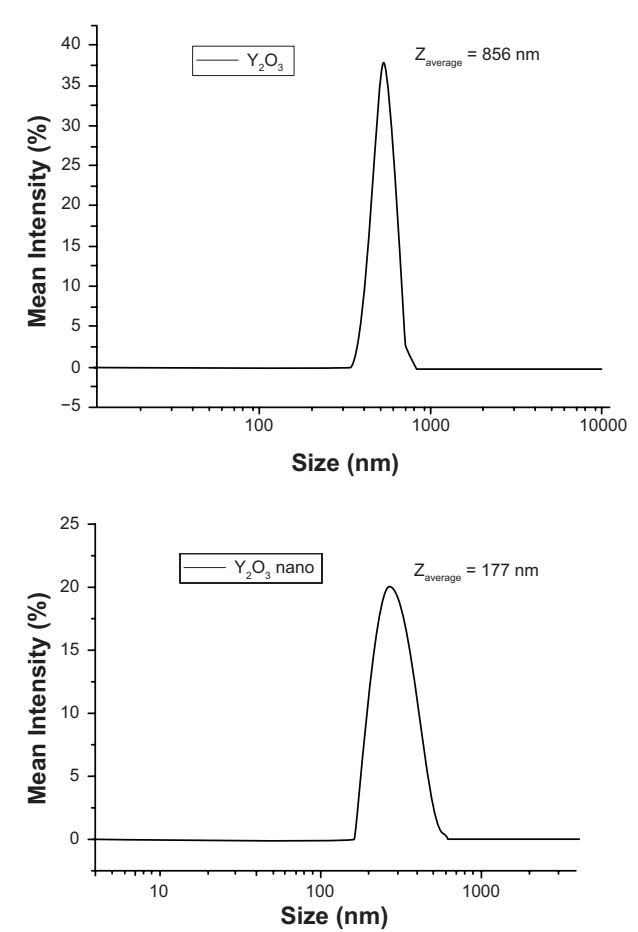

E



C
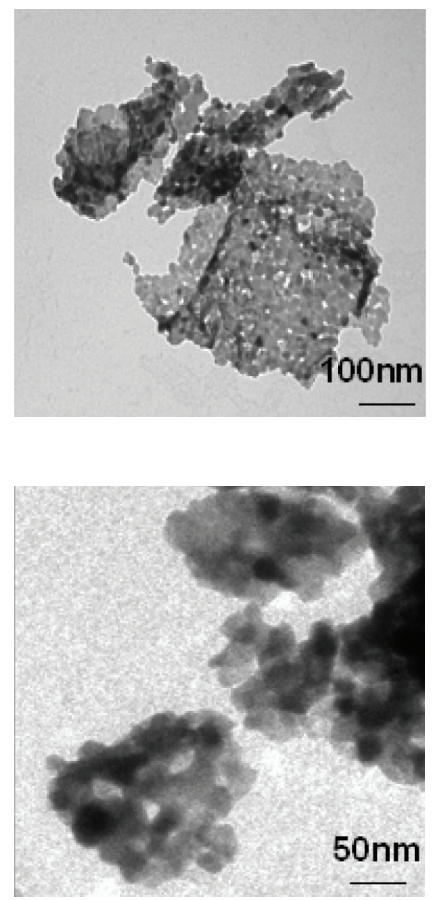

$\mathbf{F}$



Figure 3 The size-dependent effect of vacuolization induced by $\mathrm{Y}_{2} \mathrm{O}_{3}$. A) GFP-LC3/HeLa cell lines treated with $\mathrm{Y}_{2} \mathrm{O}_{3}$ nanoparticles no longer contain visible vacuoles. B, C) DLS and TEM picture showed smaller size of nano- $Y_{2} \mathrm{O}_{3}$ powder. D, E, F) The supernatant of $\mathrm{Y}_{2} \mathrm{O}_{3}$ after centrifugation at I600 rpm also showed similar results.

PtdIns 3-kinase activity, prevented autophagic process. ${ }^{18}$ Apart from that, a massive vacuolization and autophagic cell death phenomenon induced by nanosized neodymium oxide was reported in $\mathrm{H} 460$ cells. ${ }^{19}$ Although these results showed that vacuolization might have some connection with autophagy, a clear explanation of the relationship between autophagy and vacuolization is still not available. In our study, we investigated those two linked biological events induced by rare earth oxides in HeLa cell lines and proved that these two events are independent. Nanosized materials could induce autophagic effect but no vacuolization while larger sized particles could induce both. Moreover, after using Atg $5^{-/-}$MEF cells to block autophagic process, the same material still could cause massive vacuolization without autophagy.
Nanosized materials have received considerable attention in the last few years for their particular physical structure as well as biological properties. Studies have shown anticancer effects of nanoparticles and their future preclinical application appears to be promising. For example, Nano-C60 has been demonstrated to sensitize chemotherapeutic killing of normal and drug-resistant cancer cells. ${ }^{20}$ Nevertheless, yet interestingly, other results indicated diversified cellular signaling pathways involved in the various kinds of cell death caused by nanomaterials. Nano-C60 produced oxygen radicals and disrupted cellular function through lipid peroxidation in different cancer cell lines. ${ }^{21}$ Another study presented that $\mathrm{C}_{60}(\mathrm{OH})_{24}$ caused the accumulation of polyubiquitinated proteins and facilitated autophagic cell death. ${ }^{22}$ In our study, we demonstrated other than autophagy there 

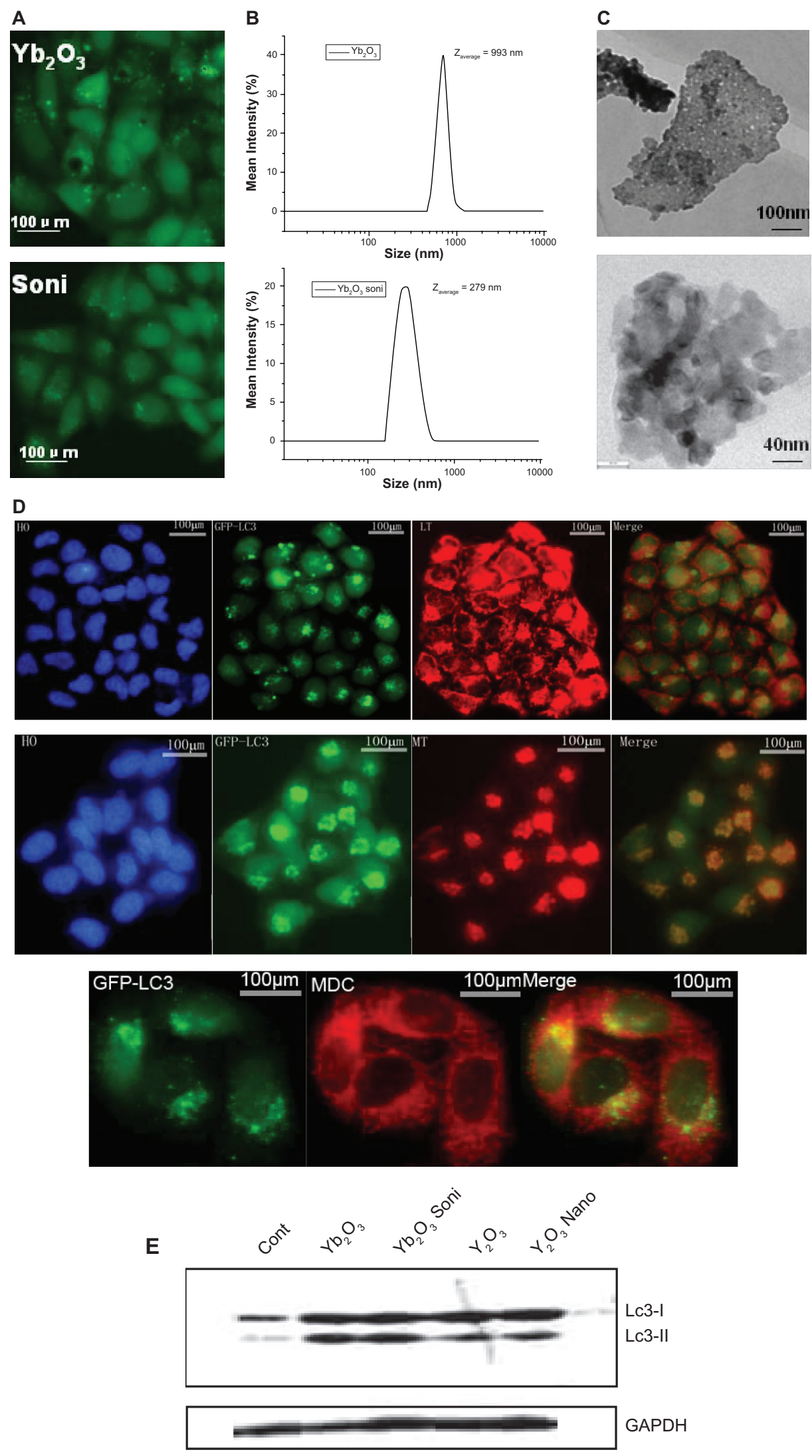

Figure 4 The size-dependent effect of vacuolization induced by $\mathrm{Yb}_{2} \mathrm{O}_{3}$. A) sonicated $\mathrm{Yb}_{2} \mathrm{O}_{3}$ no longer causes visible vacuoles in GFP-LC3/HeLa cell lines. B, C) DLS data and TEM picture showed smaller size of sonicated $\mathrm{Yb}_{2} \mathrm{O}_{3}$ compared to untreated $\mathrm{Yb}_{2} \mathrm{O}_{3}$ particles. D) Autophagic marker dye staining assay on GFP-LC3/HeLa cells treated with $50 \mu \mathrm{g} / \mathrm{mL} \mathrm{Yb} \mathrm{O}_{3}$ (sonicated) for $24 \mathrm{~h}$. E) LC3 protein type conversion. Cells were either untreated (cont) or treated with $50 \mu \mathrm{g} / \mathrm{mL}$ oxide particles for $24 \mathrm{~h}$ and collected for western blotting. 
A

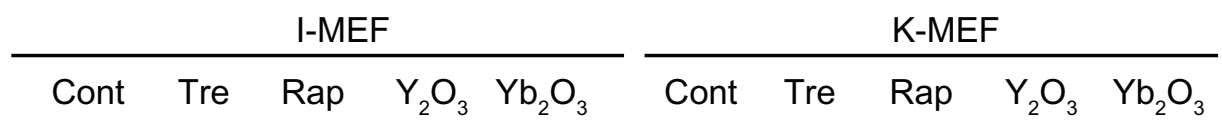

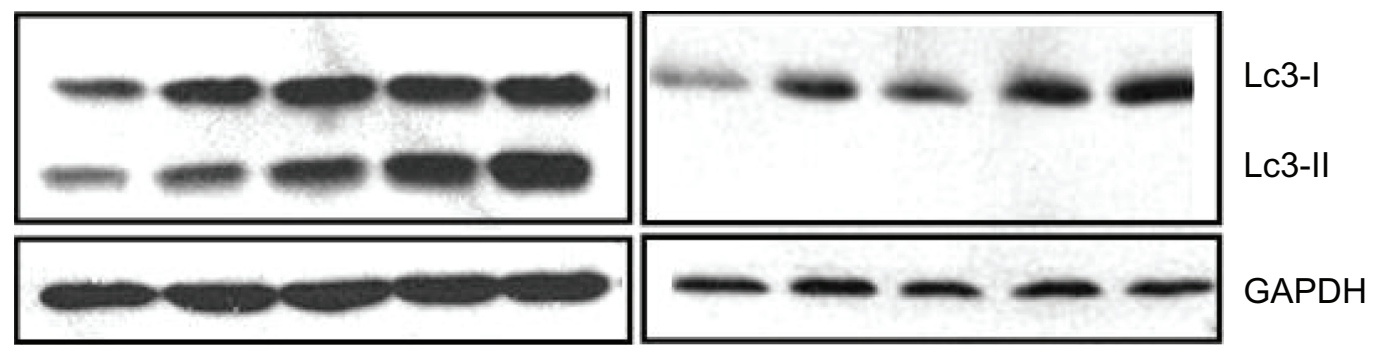

B

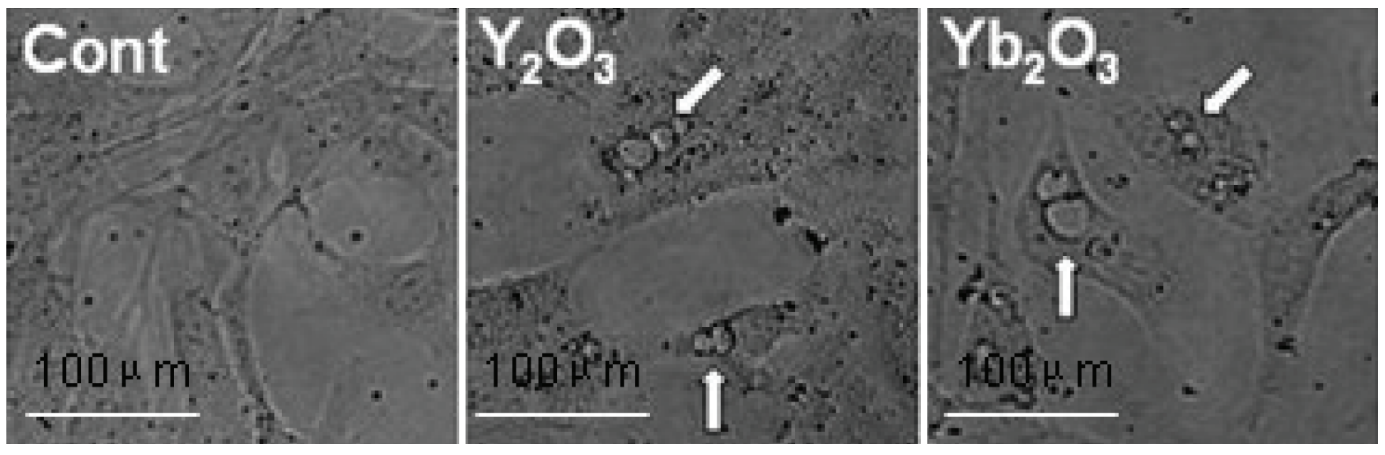

C Cont


D

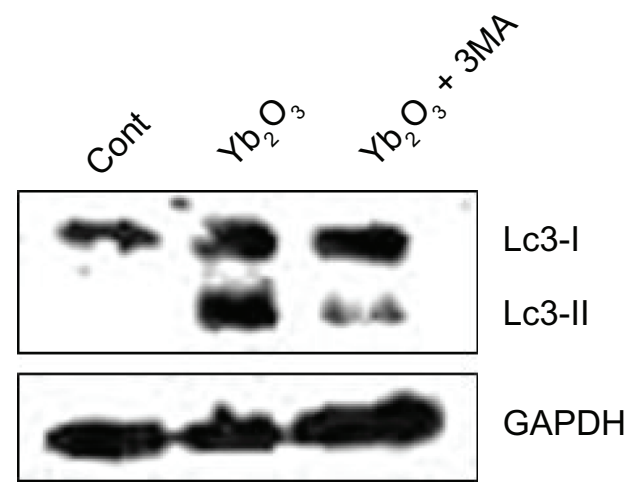

Figure 5 Massive vacuolization induced by $\mathrm{Y}_{2} \mathrm{O}_{3}, \mathrm{Yb}_{2} \mathrm{O}_{3}$ is an independent event. A) the autophagy blocking effect of Atg5 $5^{-1-} \mathrm{MEF}$ cells by western blotting. Cells were either untreated (cont) or treated with trehalose $100 \mu \mathrm{M}$, rapamycin $50 \mu \mathrm{g} / \mathrm{mL}$ (Tre, Rap, two well-known autophagy inducers as positive control), $50 \mu g / \mathrm{mL}_{2} \mathrm{O}_{3}, \mathrm{Yb}_{2} \mathrm{O}_{3}$, I-MEF $=$ immortalized wildtype MEF cells, $\mathrm{K}-\mathrm{MEF}=\mathrm{Atg} 5^{-1-}$ MEF cells. B) Direct vacuolization of K-MEF cells observed under phase contrast microscopy. C, D) 3-MA, the autophagy inducer, does not interfere with vacuolization. Cells were treated with nothing (cont), $50 \mu g / \mathrm{mL} \mathrm{Yb}_{2} \mathrm{O}_{3}, 50 \mathrm{~g} / \mathrm{mL} \mathrm{Yb}_{2} \mathrm{O}_{3}+5 \mu \mathrm{M} 3-\mathrm{MA}$. After observation under fluorescent microscopy, cells were trypsinized, collected and subject to western blotting.

is at least another pathway through which rare earth oxides develop their biological functions. Previous results suggested that taxol treatment dose-dependently increased the level of $\mathrm{Bcl}-\mathrm{X}_{\mathrm{L}}{ }^{23}$ and induced cytoplasmic vacuolization. ${ }^{24} \mathrm{Bcl}-2$ family members Bak and Bax are present in the endoplamic reticulum (ER) where they control apoptosis through the regulation of calcium levels and they are proved to be able to induce ER vacuolization via Bak. ${ }^{25}$ These results give us 
possible direction to figure out this unknown mechanism involved in this case.

In conclusion, using rare earth oxides with different sizes, we proved that the plentiful vacuolization in HeLa cells was actually caused by large aggregates of nanosized rare earth oxides. Our results showed that the formation of vacuolization was size-dependent and behaved in a different pathway from autophagy. Understanding the molecular mechanism of this pathway may help us in the future development of cancer therapy using rare earth oxides.

\section{Acknowledgments}

This work was supported by the Chinese Ministry of Sciences 973 Program (2006CB933300, 2007CB935800), Natural Science Foundation of China (\#30721002), Knowledge Innovation Program of the Chinese Academy of Sciences (KSCX2-YW-R-139, KSCX2-YW-R-21), and the Cultivation Fund of the Ministry of Education of China, NO706035).

\section{Disclosure}

No conflicts of interest were declared in relation to this paper.

\section{References}

1. Liu YN, Shi S, Mei WJ, et al. In vitro and in vivo investigations on the antiviral activity of a series of mixed-valence rare earth borotungstate heteropoly blues. Eur J Med Chem. 2008;43(9):1963-1970.

2. Liu J, Mei W, Li Y, Wang E, Ji L, Tao P. Antiviral activity of mixedvalence rare earth borotungstate heteropoly blues against influenza virus in mice. Antivir Chem Chemother. 2000;11(6):367-372.

3. Patil S, Sandberg A, Heckert E, Self W, Seal S. Protein adsorption and cellular uptake of cerium oxide nanoparticles as a function of zeta potential. Biomaterials. 2007;28(31):4600-4607.

4. Chen J, Patil S, Seal S, McGinnis JF. Rare earth nanoparticles prevent retinal degeneration induced by intracellular peroxides. Nat Nanotechnol. 2006;1(2):142-150.

5. Heckert EG, Karakoti AS, Seal S, Self W. The role of cerium redox state in the SOD mimetic activity of nanoceria. Biomaterials. 2008;29(18): 2705-2709.

6. Chen J, Patil S, Seal S, McGinnis JF. Nanoceria particles prevent ROIinduced blindness. Adv Exp Med Biol. 2008;613:53-59.

7. Park EJ, Choi J, Park YK, Park K. Oxidative stress induced by cerium oxide nanoparticles in cultured BEAS-2B cells. Toxicology. 2008; 245(1-2):90-100.
8. Wang X, Yuan L, Huang J, Zhang TL, Wang K. Lanthanum enhances in vitro osteoblast differentiation via pertussis toxin-sensitive gi protein and ERK signaling pathway. J Cell Biochem. 2008;105(5): 1307-1315.

9. Schubert D, Dargusch R, Raitano J, Chan SW. Cerium and yttrium oxide nanoparticles are neuroprotective. Biochem Biophys Res Commun. 2006;342(1):86-91.

10. Das M, Patil S, Bhargava N, et al. Auto-catalytic ceria nanoparticles offer neuroprotection to adult rat spinal cord neurons. Biomaterials. 2007;28(10):1918-1925.

11. Yu L, Lu Y, Na M, Yu SH, Wen LP. Rare earth oxide nanocrystals induce autophagy in HeLa cells. Small. 2009;5(24):2784-2787.

12. Belkin M, Hardy WG, Orr HC, Lachman AB. Induction in vitro by autonomic drugs of cytoplasmic vacuoles in ascites tumor cells. J Natl Cancer Inst. 1962;28:187-201.

13. Henics T, Wheatley DN. Cytoplasmic vacuolation, adaptation and cell death: a view on new perspectives and features. Biol Cell. 1999;91: 485-498.

14. Seleverstov O, Zabirnyk O, Zscharnack M, et al. Quantum dots for human mesenchymal stem cells labeling. A size-dependent autophagy activation. Nano Lett. 2006;6:2826-2832.

15. Pan Y, Neuss S, Leifert A, et al. Size-dependent cytotoxicity of gold nanoparticles. Small. 2007;3(11)1941-1949.

16. Chen X, Wang Z. Regulation of intracellular trafficking of the EGF receptor by Rab5 in the absence of phosphatidylinositol 3-kinase activity. EMBO Rep. 2001;2:68-74.

17. Houle S, Marceau F. Wortmannin alters the intracellular trafficking of the bradykinin B2 receptor: role of phosphoinositide 3-kinase and Rab5. Biochem J. 2003;375:151-158.

18. Blommaart EF, Krause U, Schellens JP, Vreeling-Sindelárová H, Meijer AJ. The phosphatidylinositol 3-kinase inhibitors wortmannin and LY 294002 inhibit autophagy in isolated rat hepatocytes. Eur $J$ Biochem. 1997;243(1-2)240-246.

19. Chen Y, Yang L, Feng C, et al. Nano neodymium oxide induces massive vacuolization and autophagic cell death in non-small cell lung cancer NCI-H460 cells. Biochem Biophys Res Commun. 2005;337:52-60.

20. Zhang Q, Yang W, Man N, et al. Autophagy-mediated chemosensitization in cancer cells by fullerene C60 nanocrystal. Autophagy. 2009;19:5(8).

21. Sayesa CM, Gobinb AM, et al. Colvina. Biomaterials. 2005;26: 7587-7595.

22. Yamawaki H, Iwai N. Cytotoxicity of water-soluble fullerene in vascular endothelial cells. Am J Physiol Cell Physiol. 2006;290:C1495-C1502.

23. Chun $\mathrm{E}$, Lee KY. Bcl-2 and $\mathrm{Bcl}-\mathrm{XL}$ are important for the induction paclitaxel resistance in human hepatocellular carcinoma cells. Biochem Biophys Res Commun. 2004;315:771-779.

24. Klee M, Pimentel-Muinos FX. Bcl-XL specifically activates Bak to induce swelling and restructuring of the endoplasmic reticulum. $J$ Cell Biol. 2005;168:723-734.

25. Tong-sheng C, Xiao-ping W, Lei S, Long-xiang W, Da X, Martin M. Taxol induces caspase-independent cytoplasmic vacuolization and cell death through endoplasmic reticulum (ER) swelling in ASTC-a-1 cells. Cancer Lett. 2008;270:164-172.
International Journal of Nanomedicine

\section{Publish your work in this journal}

The International Journal of Nanomedicine is an international, peerreviewed journal focusing on the application of nanotechnology in diagnostics, therapeutics, and drug delivery systems throughou the biomedical field. This journal is indexed on PubMed Central, MedLine, CAS, SciSearch ${ }^{\circledR}$, Current Contents ${ }^{\circledR} /$ Clinical Medicine,

\section{Dovepress}

Journal Citation Reports/Science Edition, EMBase, Scopus and the Elsevier Bibliographic databases. The manuscript management system is completely online and includes a very quick and fair peer-review system, which is all easy to use. Visit http://www.dovepress.com/ testimonials.php to read real quotes from published authors. 